\title{
Cost-Effectiveness of Liraglutide Versus Dapagliflozin for the Treatment of Patients with Type 2 Diabetes Mellitus in the UK
}

\author{
Gabriela Vega-Hernandez $\cdot$ Radek Wojcik $\cdot$ Max Schlueter
}

Received: December 6, 2016 / Published online: March 27, 2017

(C) The Author(s) 2017. This article is an open access publication

\section{ABSTRACT}

Introduction: To date there is a lack of economic analysis comparing glucagon-like peptide-1 receptor agonists (GLP-1RAs) to sodium-glucose co-transporter 2 inhibitors (SGLT-2i) for the treatment of type 2 diabetes mellitus (T2DM). Liraglutide and dapagliflozin are the most commonly prescribed GLP-1RA and SGLT-2i in the UK. This analysis investigated the cost-effectiveness of liraglutide 1.2 and $1.8 \mathrm{mg} /$ day compared to dapagliflozin $10 \mathrm{mg} /$ day for the treatment of T2DM in the UK in patients on dual and triple antidiabetic therapy.

Methods: Cost-effectiveness analysis was conducted in the QuintilesIMS CORE Diabetes Model (CDM). The model estimated expected costs and outcomes over a lifetime horizon using the UK national payer perspective. Liraglutide

Enhanced content To view enhanced content for this article go to http://www.medengine.com/Redeem/ 17F7F060606BDCD7.

Electronic supplementary material The online version of this article (doi:10.1007/s13300-017-0250-y) contains supplementary material, which is available to authorized users.

G. Vega-Hernandez

Novo Nordisk Ltd, London, UK

R. Wojcik · M. Schlueter $(\bowtie)$

QuintilesIMS, London, UK

e-mail: mschlueter@uk.imshealth.com efficacy estimates and patient characteristics were sourced from a trial in patients on prior metformin monotherapy, and from a trial in patients on prior combination therapy. Comparative efficacy data for the other interventions were derived from a network meta-analysis. Utility inputs were extracted from a systematic literature review. Costs are presented in Great British Pound (GBP), 2016 values.

Results: In dual and triple therapy, liraglutide $1.2 \mathrm{mg}$ was less costly and more effective compared with dapagliflozin $10 \mathrm{mg}$, providing a QALY gain of 0.04 and cost savings of GBP 11 per patient in dual therapy, and a QALY gain of 0.06 and cost savings of GBP 71 per patient in triple therapy. For liraglutide $1.8 \mathrm{mg}$, increased efficacy and costs compared with dapagliflozin $10 \mathrm{mg}$ were observed in both dual and triple therapy. In dual therapy, a QALY gain of 0.07 and additional costs of GBP 888 per patient yielded an ICER of GBP 13,227, whereas in triple therapy a QALY gain of 0.07 and additional cost of GBP 791 per patient gave an ICER of 11,857. Conclusion: This long-term modelling analysis found that both dosages of liraglutide may be cost-effective treatment alternatives as part of a dual or a triple antidiabetic therapy in patients for whom an SGLT-2i therapy is considered.

Funding: Novo Nordisk.

Keywords: Cost-effectiveness analysis; Glucagon-like peptide 1; Sodium-glucose transporter 2; Type 2 diabetes mellitus 


\section{INTRODUCTION}

Diabetes imposes a substantial societal and financial burden globally. In the UK, the prevalence of diabetes is $6 \%$ in people aged 20-79 years [1] and it accounts for $10 \%$ of the overall health expenditure [1]. The total economic cost of type 2 diabetes mellitus (T2DM) amounted to GBP 21.8 billion in 2010/11 [2], including both direct and indirect costs.

Glucagon-like peptide-1 receptor agonists (GLP-1RA) are a class of glucose-lowering drugs currently used in the UK for the treatment of T2DM. Guidelines for the treatment of T2DM by the National Institute for Health and Care Excellence (NICE) [3] recommend the use of GLP-1RAs in triple therapy when previous triple therapy with oral antidiabetes drugs (OADs) is not effective, not tolerated, or contraindicated [3].

Currently, there is evidence assessing the cost-effectiveness of the GLP1-RA liraglutide versus other GLP-1RAs $[4,5]$. However, there is a lack of health economic analyses comparing liraglutide to SGLT-2is. The aim of this analysis was to assess the cost-effectiveness of liraglutide 1.2 and $1.8 \mathrm{mg} /$ day, the most commonly used GLP-1RA in the UK, with dapagliflozin $10 \mathrm{mg}$, the most commonly used SGLT-2i in the UK, for the treatment of T2DM as part of a dual and a triple antidiabetic therapy.

This article does not contain any new studies with human or animal subjects performed by any of the authors.

\section{METHODS}

This study used the CORE Diabetes Model (CDM), a widely published and previously validated simulation model [6-11]. The CDM estimates long-term health and cost outcomes of interventions in diabetes taking into account population characteristics at baseline and accounting for evolution of a range of microand macrovascular complications over a set time horizon. Model outputs include economic consequences, incidence of complications, life years and quality-adjusted life years (QALYs) gained, as well as incremental cost-effectiveness ratios (ICERs).

The interventions included in the study were the daily GLP-1RA liraglutide $1.2 \mathrm{mg}$ daily and liraglutide $1.8 \mathrm{mg}$ daily and the SGLT-2i dapagliflozin $10 \mathrm{mg}$ daily. The current analyses assessed the interventions as dual or triple therapies in the management of patients with T2DM in the UK.

Patient baseline characteristics for the dual therapy analysis, including glycemia, cardiovascular risk factors, and the presence of existing diabetic complications, were taken from the NN2211-1860 study [12], Table 1 . This was an international, open-label, randomized trial of patients with T2DM who had inadequate glycemic control on metformin and who were randomized to receive 1.2 or $1.8 \mathrm{mg}$ liraglutide once daily, subcutaneously or $100 \mathrm{mg}$ sitagliptin once daily, orally. Patient baseline characteristics for the triple therapy analysis were derived from the Liraglutide Effect and Action in Diabetes 4 (LEAD-4) study, a double-blind, randomized, placebo-controlled, parallel-group, multicenter trial [13] in which patients were randomized to receive 1.2 or $1.8 \mathrm{mg}$ of once-daily liraglutide or liraglutide placebo injected subcutaneously in combination with metformin and rosiglitazone in all three treatment groups. The proportion of smokers and alcohol consumption data were not available from the trials and were obtained from the World Health Organization [14] and Health and Social Care Information Centre (HSCIC) statistics on smoking [15].

As a result of the lack of head-to-head clinical trials comparing the efficacy of liraglutide versus dapagliflozin, estimation of the relative treatment effects between the interventions was derived from a network meta-analysis (NMA) [16]. The NMA included 17 randomized controlled trials (RCTs) (8784 patients), which were broadly consistent with the NN2211-1860 and LEAD-4 trials in terms of key baseline characteristics such as age and BMI (Table A1 in the online supplementary material); baseline HbA1c in the NN2211-1860 and LEAD-4 studies was at the upper end of trials included in the NMA. 
Table 1 Patient baseline characteristics

\begin{tabular}{|c|c|c|c|c|}
\hline \multirow[t]{2}{*}{ Parameter } & \multicolumn{2}{|l|}{ Dual therapy } & \multicolumn{2}{|l|}{ Triple therapy } \\
\hline & Mean (SD) or \% & References & Mean (SD) or \% & $\overline{\text { References }}$ \\
\hline Age & $55.30(9.2)$ & {$[12]$} & $55.00(10.34)$ & [13] \\
\hline Duration of diabetes & $6.20(5.1)$ & {$[12]$} & $9.00(6.0)$ & [13] \\
\hline Proportion male & $52.9 \%$ & {$[12]$} & $56.7 \%$ & [13] \\
\hline Proportion white & $71.4 \%^{\mathrm{b}}$ & {$[12]$} & $70.8 \%^{\mathrm{b}}$ & [13] \\
\hline Proportion black & $8.3 \%^{\mathrm{b}}$ & {$[12]$} & $12.2 \%^{\mathrm{b}}$ & [13] \\
\hline Proportion Hispanic & $17.3 \%^{\mathrm{b}}$ & {$[12]$} & $12.9 \%^{\mathrm{b}}$ & [13] \\
\hline Proportion Asian/Pacific Islander & $3.0 \%^{\mathrm{b}}$ & {$[12]$} & $1.5 \%^{\mathrm{b}}$ & [13] \\
\hline HbAlc (\%) & $8.40(0.80)$ & {$[12]$} & $8.50(1.20)$ & [13] \\
\hline Systolic blood pressure $(\mathrm{mmHg})$ & $132.20(14.50)$ & {$[12]$} & $127.7(14.56)$ & [13] \\
\hline Diastolic blood pressure $(\mathrm{mmHg})$ & $81.20(8.90)$ & {$[12]$} & $75.7(8.88)$ & [13] \\
\hline Triglycerides $(\mathrm{mg} / \mathrm{dL})$ & $210.80(196.63)^{c}$ & {$[11]$} & $222.10(206.20)$ & [34] \\
\hline HDL-C (mg/dL) & $44.86(11.99)^{\mathrm{c}}$ & {$[11]$} & $48.70(11.70)$ & [34] \\
\hline LDL-C (mg/dL) & $102.48(31.71)^{\mathrm{c}}$ & {$[11]$} & $110.30(38.50)$ & [34] \\
\hline Total cholesterol (mg/dL) & $185.23(14.69)^{\mathrm{c}}$ & {$[11]$} & $195.40(52.80)$ & [34] \\
\hline BMI $\left(\mathrm{kg} / \mathrm{m}^{2}\right)$ & $32.80(5.20)$ & {$[12]$} & $33.53(5.24)$ & {$[34]$} \\
\hline Proportion smoker & $16.0 \%$ & {$[15]$} & $16.0 \%$ & [15] \\
\hline Cigarettes per day & 12 & {$[15]$} & 12 & {$[15]$} \\
\hline Alcohol consumption (ml/week) & 8.3 & {$[14]$} & 8.3 & [14] \\
\hline Proportion myocardial infarction & $2.7 \%$ & {$[11]$} & $5.8 \%$ & {$[34]$} \\
\hline Proportion angina & $1.8 \%$ & {$[11]$} & $2.6 \%$ & {$[34]$} \\
\hline Proportion peripheral vascular disease & $0.9 \%$ & {$[11]$} & $0.4 \%$ & [34] \\
\hline Proportion stroke & $0.8 \%$ & {$[11]$} & $1.1 \%$ & {$[34]$} \\
\hline Proportion heart failure & $0.4 \%$ & {$[11]$} & $0.8 \%$ & [34] \\
\hline Proportion atrial fibrillation & $1.5 \%$ & {$[11]$} & $0.6 \%$ & [34] \\
\hline Proportion left ventricular hypertrophy & $0.2 \%$ & {$[11]$} & $0.2 \%$ & {$[34]$} \\
\hline Proportion microalbuminuria & $1.1 \%$ & {$[11]$} & $3.9 \%$ & {$[34]$} \\
\hline Proportion gross proteinuria & $0.2 \%$ & {$[11]$} & $0.6 \%$ & {$[34]$} \\
\hline Proportion end-stage renal disease & $0.4 \%$ & {$[11]$} & $0.2 \%$ & [34] \\
\hline Proportion background diabetic retinopathy & $2.7 \%$ & {$[11]$} & $2.3 \%$ & {$[34]$} \\
\hline Proportion proliferative diabetic retinopathy & $0.2 \%$ & {$[11]$} & $0.2 \%$ & {$[34]$} \\
\hline Proportion severe vision loss & $0.4 \%$ & {$[11]$} & $0.2 \%$ & [34] \\
\hline Proportion macular edema & $1.1 \%$ & {$[11]$} & $0.0 \%$ & [34] \\
\hline
\end{tabular}


Table 1 continued

\begin{tabular}{llllll}
\hline Parameter & \multicolumn{2}{l}{ Dual therapy } & & \multicolumn{2}{l}{ Triple therapy } \\
\cline { 2 - 3 } \cline { 5 - 6 } \cline { 5 - 6 } & Mean $(\mathbf{S D})$ or \% & References & & Mean (SD) or \% & References \\
\hline Proportion cataract & $1.7 \%$ & {$[11]$} & & $5.8 \%$ & {$[34]$} \\
Proportion uninfected ulcer & $0.6 \%$ & {$[11]$} & $0.2 \%$ & {$[34]$} \\
Proportion infected ulcer & $0.3 \%$ & {$[11]$} & $0.0 \%^{\mathrm{a}}$ & $\mathrm{N} / \mathrm{A}$ \\
Proportion healed ulcer & $0.0 \%$ & {$[11]$} & & $0.0 \%^{\mathrm{a}}$ & $\mathrm{N} / \mathrm{A}$ \\
Proportion history of amputation & $0.0 \%$ & {$[11]$} & & $0.8 \%$ & {$[34]$} \\
Proportion neuropathy & $11.6 \%$ & {$[11]$} & $3.2 \%$ & {$[34]$} \\
\hline
\end{tabular}

$B M I$ body mass index, $H D L$ high density lipoprotein, $L D L$ low density lipoprotein

${ }^{a}$ Not reported-assumed $0 \%$

b Other ethnicity categories were evenly split among the categories reported in this table

${ }^{c}$ Values converted from $\mathrm{mmol} / \mathrm{L}$ to $\mathrm{mg} / \mathrm{dL}$

NMA results indicated a greater percentage $\mathrm{HbA1c}$ reduction with liraglutide $1.2 \mathrm{mg}$ (mean difference $-0.64 ; 95 \%$ confidence interval $[\mathrm{CI}]$ $-0.94,-0.34$ ) and $1.8 \mathrm{mg}$ (mean difference -0.81 ; $95 \%$ CI $-1.11,-0.51$ ) versus dapagliflozin $10 \mathrm{mg}$. Efficacy and safety parameters included in the model but not reported in the NMA were assumed equivalent in all arms.

The relative treatment effects reported in the NMA were then applied to the estimates for liraglutide on HbA1c, systolic blood pressure, weight, and hypoglycemic events (severe and mild) as reported in the NN2211-1860 and LEAD-4 studies in order to obtain estimates for dapagliflozin.

In the base case, all treatment arms assumed that patients remained on active treatment for a period of 3 years, followed by a switch to insulin glargine at a dose of 40 international units (IU) daily [17].

Long-term progressions of $\mathrm{HbA1c}$, blood pressure, and lipids were estimated using UKPDS 68 risk equations [18]. BMI differences between the interventions were applied during the time on treatment only; patients were assumed to rebound to baseline values after treatment is changed to insulin at 3 years.

The model estimated expected costs and outcomes over a lifetime horizon adopting a UK national payer perspective (National Health Service). Only direct costs were considered.
Annual therapy costs were calculated using daily doses of the interventions within the scope of the analysis. Unit costs of drugs, injection needles, and the self-monitoring of blood glucose were derived from the British National Formulary (BNF) and the Monthly Index of Medical Specialities (MIMS) [19, 20]. Underlying assumptions of drug management costs, derived from the BNF [19], were $20 \mathrm{mg}$ statins (atorvastatin) daily, $2.5 \mathrm{mg}$ angiotensin-converting enzyme (ACE) inhibitors (ramipril) twice-daily, and additionally $75 \mathrm{mg}$ aspirin daily for patients with cardiovascular disease only. Costs associated with screening tests for eye disease, proteinuria, depression, and foot screening programs were taken from the Personal Social Services Research Unit (PSSRU) [21]. The cost of diabetes-related complications was obtained from published literature, inflated to 2015 values using the PSSRU Pay \& Price index [21] wherever necessary. Costs of background OAD therapy were not included as these were expected to be equal in both treatment arms. In the base case, a discount rate of $3.5 \%$ was applied to future costs and outcomes, as per NICE guidelines [22]. Unit costs used in this study are presented in Table 2.

Health state utilities were derived from a published systematic literature review of utility values associated with T2DM [23] and are presented in Table 3 . The disutility associated with 
Table 2 Unit costs of diabetes management and complications

\begin{tabular}{|c|c|c|}
\hline Cost category & Cost (GBP) & References \\
\hline \multicolumn{3}{|l|}{ Management costs } \\
\hline Liraglutide $1.2 \mathrm{mg}$ (annual) & 955.49 & {$[19]$} \\
\hline Liraglutide 1.8 mg daily (annual) & 1433.24 & {$[19]$} \\
\hline Dapagliflozin 10 mg daily (annual) & 445.48 & {$[19]$} \\
\hline Insulin glargine 40 IU daily (annual) & 404.21 & {$[19]$} \\
\hline Statins (annual) & 18.00 & {$[19]$} \\
\hline Aspirin (annual) & 10.56 & {$[19]$} \\
\hline ACEs (annual) & 14.61 & {$[19]$} \\
\hline Eye screening & 33.98 & {$[35]$} \\
\hline Microalbuminuria screening & 14.55 & {$[19,21]$} \\
\hline Gross proteinuria screening & 14.53 & {$[19,21]$} \\
\hline Foot screening program & 130.00 & {$[21]$} \\
\hline \multicolumn{3}{|l|}{ Direct costs of cardiovascular complications } \\
\hline Myocardial infarction 1 st year & 5647.76 & {$[36]$} \\
\hline Myocardial infarction subsequent years & 634.56 & {$[36]$} \\
\hline Angina 1st year & 2908.55 & {$[37,38]$} \\
\hline Angina subsequent years & 1947.54 & {$[37,38]$} \\
\hline Congestive heart failure 1st year & 2718.80 & {$[36]$} \\
\hline Congestive heart failure subsequent years & 590.69 & {$[36]$} \\
\hline Stroke 1st year & 9499.99 & {$[36]$} \\
\hline Stroke subsequent years & 2553.53 & {$[36]$} \\
\hline Stroke death within 30 days & $10,178.42$ & {$[39]$} \\
\hline Peripheral vascular disease & 1708.28 & {$[35]$} \\
\hline \multicolumn{3}{|l|}{ Direct costs of renal complications } \\
\hline Hemodialysis 1st year & $41,436.97$ & {$[40]$} \\
\hline Hemodialysis subsequent years & $41,436.97$ & {$[40]$} \\
\hline Peritoneal dialysis 1st year & $22,787.93$ & {$[40]$} \\
\hline Peritoneal dialysis subsequent years & $22,787.93$ & {$[40]$} \\
\hline Renal transplant 1st year & $24,486.55$ & {$[40]$} \\
\hline Renal transplant subsequent years & 7958.49 & {$[40]$} \\
\hline \multicolumn{3}{|l|}{ Direct costs of acute events } \\
\hline Major hypoglycemia (per event) & 384.61 & {$[41]$} \\
\hline Minor hypoglycemia (per event) & 4.61 & {$[42]^{a}$} \\
\hline
\end{tabular}


Table 2 continued

\begin{tabular}{lcc}
\hline Cost category & Cost (GBP) & References \\
\hline Direct costs of eye disease & & \\
Laser treatment & 119.28 & {$[35]$} \\
Cataract operation & 857.78 & {$[35]$} \\
Cost following cataract operation & 504.99 & {$[43]$} \\
Blindness & 5601.86 & {$[44]$} \\
Direct costs of neuropathy, foot ulcer and amputation & & {$[35]$} \\
Neuropathy & 968.49 & {$[35]$} \\
Amputation & $11,336.13$ & {$[35]$} \\
Amputation prosthesis & 2064.86 & {$[45]$} \\
Gangrene treatment (monthly) & $41,679.78$ \\
After healed ulcer & 263.20 & {$[45]$} \\
Infected ulcer (monthly) & $23,896.88$ \\
Uninfected ulcer (monthly) & $23,428.62$ & {$[45]$} \\
Healed ulcer history of amputation & 263.20 & {$[45]$}
\end{tabular}

HCP health care professional

a Based on a HCP visit following a hypo episode and average number of self-monitoring of blood glucose (SMBG) tests

loss of health-related quality of life due to an increase in BMI was applied as per the CODE-2 study by Bagust and Beale [24]. A diminishing approach was used to estimate utility decrements associated with non-severe hypoglycemia, based on results of a study by Lauridsen et al. [25].

The primary analysis considered was the incremental cost per QALY gained with each daily dose of liraglutide compared to dapagliflozin $10 \mathrm{mg} /$ day. A number of sensitivity analyses were conducted to assess the impact of parameters on the base case cost-effectiveness results. One-way sensitivity analyses included variations in the discount rate (between $0 \%$ and $6 \%)$, time horizon $(20,30$, and 40 years), and alternative risk equations (UKPDS82). The impact of the cost of diabetes-related complications was tested by varying these costs on $\pm 10 \%$ of the mean value. We also tested the impact of using alternative costs sourced from a recent UK study of immediate and long-term costs of T2DM-related complications [26].
Management costs were varied by $\pm 20 \%$ of their mean values. For the efficacy parameters, the effect of abolishing BMI and systolic blood pressure treatment differences was investigated.

Four scenario analyses were tested. The first scenario explored the impact of simulating more severe patients by using the upper limit of 95\% confidence interval of the HbA1c value at baseline. A second scenario considered a treatment duration based on disease progression according to UKPDS 68 risk equations; patients remain on active treatment until their level of HbA1c reached $7.5 \%$, at which point they were assumed to switch to insulin glargine. A third scenario analysis tested the impact of using a dose of $1.35 \mathrm{mg}$ /day for liraglutide, reflective of the average daily dose in UK [27], for which costs and effects were linearly interpolated between the 1.2 and $1.8 \mathrm{mg}$ doses. Finally, a fourth scenario explored the impact of comparing liraglutide with SGLT-2is as a class. Data from QuintilesIMS MIDAS was used to derive the current market shares of liraglutide 1.2 and 
Table 3 Health-related utility and disutility values based on a systematic review of T2DM utility values [23]

\begin{tabular}{|c|c|c|}
\hline Health state/event & Health-related utility/disutility & References \\
\hline T2DM no complications & 0.785 & {$[46]$} \\
\hline Myocardial infarction event & -0.055 & {$[46]$} \\
\hline Post MI & 0.730 & {$[46]$} \\
\hline Angina & 0.695 & {$[46]$} \\
\hline Congenital heart failure & 0.677 & {$[46]$} \\
\hline Stroke event & -0.164 & {$[46]$} \\
\hline Post stroke & 0.621 & {$[46]$} \\
\hline Peripheral vascular disease & 0.724 & {$[24]$} \\
\hline Microalbuminuria & 0.785 & {$[46]^{a}$} \\
\hline Gross renal proteinuria & 0.785 & {$[46]^{\mathrm{a}}$} \\
\hline Hemodialysis & 0.621 & {$[47]$} \\
\hline Peritoneal dialysis & 0.581 & {$[47]$} \\
\hline Renal transplant & 0.762 & {$[48]$} \\
\hline Background diabetic retinopathy (BDR) & 0.745 & [49] \\
\hline $\mathrm{BDR}$ wrongly treated & 0.745 & {$[49]$} \\
\hline $\begin{array}{l}\text { Proliferative diagnostic retinopathy laser treated } \\
\text { (proliferative diabetic retinopathy) }\end{array}$ & 0.785 & {$[46]^{\mathrm{a}}$} \\
\hline $\begin{array}{l}\text { Proliferative diagnostic retinopathy no laser } \\
\text { (proliferative diabetic retinopathy) }\end{array}$ & 0.785 & {$[46]^{\mathrm{a}}$} \\
\hline Macular edema & 0.745 & {$[49]$} \\
\hline Severe vision loss/blindness & 0.711 & {$[46]$} \\
\hline Cataract & 0.769 & {$[50]$} \\
\hline Neuropathy & 0.701 & {$[24]$} \\
\hline Healed ulcer & 0.785 & {$[46]$} \\
\hline Active ulcer & 0.615 & {$[24]$} \\
\hline Amputation, year of event & -0.280 & {$[46]$} \\
\hline Post-amputation ( $2+$ years after event $)$ & 0.505 & {$[46]$} \\
\hline Severe hypoglycemia events & -0.062 & {$[51]^{\mathrm{b}}$} \\
\hline Non-severe hypoglycemia event & -0.005 & {$[51]^{\mathrm{b}}$} \\
\hline Nausea event & -0.01 & {$[51]$} \\
\hline Depression not treated & 0.785 & {$[46]^{a}$} \\
\hline Depression treated & 0.785 & {$[46]^{a}$} \\
\hline
\end{tabular}


Table 3 continued

\begin{tabular}{llll}
\hline Health state/event & Health-related utility/disutility & References \\
\hline Each unit of BMI over $25 \mathrm{~kg} / \mathrm{m}^{2}$ & -0.0061 & {$[24]$} & \\
\hline a Assumed same as no complications & & & \\
b Value for UK population & &
\end{tabular}

$1.8 \mathrm{mg}$, dapagliflozin 5 and $10 \mathrm{mg}$, empagliflozin 10 and $25 \mathrm{mg}$, and canagliflozin 100 and $300 \mathrm{mg}$ in the UK. A weighted average of the treatment effects of included SGLT-2i treatments from the NMA was applied for this scenario analysis.

Finally, probabilistic sensitivity analysis was conducted for all base case analyses, using 500 simulations with 25,000 patients throughout.

\section{RESULTS}

\section{Base Case: Dual Therapy}

In the base case analysis, liraglutide $1.2 \mathrm{mg}$ generated higher QALYs (0.039 per patient) and lower costs (GBP 11 per patient) compared with dapagliflozin $10 \mathrm{mg}$. Liraglutide $1.2 \mathrm{mg}$ also showed increases in life expectancy compared to dapagliflozin $10 \mathrm{mg}$. Whilst higher treatment costs were observed for liraglutide $1.2 \mathrm{mg}$ than for dapagliflozin $10 \mathrm{mg}$ (GBP 1532 per patient), complication costs were on average lower for liraglutide $1.2 \mathrm{mg}$, overall resulting in lower total costs with liraglutide. Differences in complication cost between liraglutide $1.2 \mathrm{mg}$ and dapagliflozin $10 \mathrm{mg}$ were due to lower incidence of renal, eye, ulcer, amputation, and neuropathy-related complications associated with liraglutide $1.2 \mathrm{mg}$. Patients treated with liraglutide $1.2 \mathrm{mg}$ on average were free of complications for three additional months compared with patients on dapagliflozin $10 \mathrm{mg}$. Base case results are reported in Table 4 .

In the base case analysis of liraglutide $1.8 \mathrm{mg}$ compared with dapagliflozin $10 \mathrm{mg}$, liraglutide $1.8 \mathrm{mg}$ produced higher life expectancy and QALYs than dapagliflozin $10 \mathrm{mg}$. Liraglutide $1.8 \mathrm{mg}$ was also associated with higher total costs relative to dapagliflozin $10 \mathrm{mg}$ (GBP 888 per patient). As with liraglutide $1.2 \mathrm{mg}$, liraglutide $1.8 \mathrm{mg}$ was associated with higher treatment costs but lower complication costs compared to dapagliflozin $10 \mathrm{mg}$, with fewer renal, ulcer, amputation, neuropathy, and eye-related complications. Overall, liraglutide $1.8 \mathrm{mg}$ compared to dapagliflozin $10 \mathrm{mg}$ generated an ICER of GBP 13,227 per QALY gained.

\section{Base Case: Triple Therapy}

In the base case analysis of liraglutide $1.2 \mathrm{mg}$ versus dapagliflozin $10 \mathrm{mg}$, liraglutide $1.2 \mathrm{mg}$ yielded a QALY gain of 0.064 and lower costs of GBP -261, resulting in liraglutide $1.2 \mathrm{mg}$ dominating dapagliflozin $10 \mathrm{mg}$. In the base case analysis of liraglutide $1.8 \mathrm{mg}$ compared with dapagliflozin $10 \mathrm{mg}$, liraglutide $1.8 \mathrm{mg}$ produced a QALY gain of 0.067 and incremental costs of GBP 791, giving an ICER of GBP 11,857 per QALY gained.

\section{Sensitivity Analyses}

In both dual and triple therapy, liraglutide $1.2 \mathrm{mg}$ remained either dominant (more effective and less costly) or cost-effective compared to dapagliflozin $10 \mathrm{mg}$ in the majority of sensitivity analyses. The cost-effectiveness of liraglutide $1.2 \mathrm{mg}$ was most sensitive to a discount rate of $0 \%$ applied to costs and outcomes, to a treatment switch at 5 years, and to a lowering of the time horizon to 10 years. Liraglutide $1.8 \mathrm{mg}$ also remained cost-effective across the majority of analyses performed in both dual and triple therapy, mostly generating ICERs below GBP 20,000 per QALY gained. Overall, sensitivity analysis calculating undiscounted costs and outcomes, shortening the time horizon to 10 years, and extending the treatment 
Table 4 Base case results: liraglutide vs dapagliflozin

\begin{tabular}{|c|c|c|c|c|c|c|}
\hline & $\begin{array}{l}\text { Liraglutide } \\
1.2 \mathrm{mg}\end{array}$ & $\begin{array}{l}\text { Dapagliflozin } \\
10 \mathrm{mg}\end{array}$ & Incremental & $\begin{array}{l}\text { Liraglutide } \\
1.8 \mathrm{mg}\end{array}$ & $\begin{array}{l}\text { Dapagliflozin } \\
10 \mathrm{mg}\end{array}$ & Incremental \\
\hline \multicolumn{7}{|l|}{ Dual therapy } \\
\hline QALYs & 10.169 & 10.131 & 0.039 & 10.198 & 10.131 & 0.067 \\
\hline $\begin{array}{l}\text { Life expectancy } \\
\text { (years) }\end{array}$ & 15.223 & 15.197 & 0.027 & 15.258 & 15.197 & 0.061 \\
\hline $\begin{array}{l}\text { Lifetime costs } \\
(\mathrm{GBP})\end{array}$ & 64,239 & 64,250 & -11 & 65,137 & 64,250 & 888 \\
\hline \multicolumn{3}{|c|}{ ICER (incremental costs/incremental life expectancy) } & \multicolumn{3}{|l|}{ Dominant } & $13,227.00$ \\
\hline \multicolumn{3}{|c|}{ ICER (incremental costs/incremental QALYs) } & Dominant & & & $14,432.00$ \\
\hline \multicolumn{7}{|l|}{ Triple therapy } \\
\hline QALYs & 10.184 & 10.12 & 0.064 & 10.187 & 10.12 & 0.067 \\
\hline $\begin{array}{l}\text { Life expectancy } \\
\text { (years) }\end{array}$ & 15.345 & 15.294 & 0.051 & 15.35 & 15.294 & 0.056 \\
\hline $\begin{array}{l}\text { Lifetime costs } \\
\text { (GBP) }\end{array}$ & 63,158 & 63,229 & -71 & 64,020 & 63,229 & 791 \\
\hline \multicolumn{3}{|c|}{ ICER (incremental costs/incremental life expectancy) } & Dominant & & & $11,857.00$ \\
\hline \multicolumn{3}{|c|}{ ICER (incremental costs/incremental QALYs) } & Dominant & & & $14,250.00$ \\
\hline
\end{tabular}

duration to 5 years had the most significant impact on the ICER. Results of all univariate sensitivity analyses for dual and triple therapy are presented in Table 5 and 6 , respectively.

Scenario analysis explored the cost-effectiveness when comparing liraglutide to the weighted average costs and effects of SGLT-2is as an entire class. Assuming a willingness-to-pay (WTP) threshold between GBP 20,000 and GBP 30,000 per QALY gained, both liraglutide doses remained cost-effective versus the entire class of SGLT-2is, with ICERs ranging between GBP 2000 and GBP 21,000.

Finally, probabilistic sensitivity analysis (PSA) for the dual therapy analysis yielded respective ICERs for liraglutide 1.2 and $1.8 \mathrm{mg}$ of GBP 2178 and GBP 18,154 per QALY gained. In the triple therapy comparison, PSA generated ICERs of GBP 1850 and GBP 16,156 per QALY gained for liraglutide 1.2 and $1.8 \mathrm{mg}$, respectively. Cost-effectiveness planes from PSA in dual and triple therapy for liraglutide 1.2 and $1.8 \mathrm{mg}$ are presented in Fig. 1 and suggest that the majority of bootstrap samples were located in the north-eastern quadrant, denoting higher QALYs as well as higher costs for liraglutide 1.2 and $1.8 \mathrm{mg}$ compared to dapagliflozin $10 \mathrm{mg}$. Cost-effectiveness acceptability curves (CEACs) presented in Fig. 2 suggest a respective probability for liraglutide 1.2 and $1.8 \mathrm{mg}$ of $85 \%$ and $49 \%$ of being cost-effective in triple therapy at a willingness-to-pay (WTP) threshold of GBP 20,000, whereas the probability of cost-effectiveness of liraglutide 1.2 and $1.8 \mathrm{mg}$ in dual therapy amounted to $70 \%$ and $48 \%$, respectively, at the same WTP threshold.

\section{DISCUSSION}

This analysis explored the cost-effectiveness of liraglutide compared to dapagliflozin, the most commonly used GLP-1RA and SGLT-2i treatments in the UK, for the treatment of T2DM in patients on dual and on triple antidiabetic 
Table 5 Summary of sensitivity analyses: dual therapy

\begin{tabular}{|c|c|c|c|c|c|c|}
\hline & \multicolumn{3}{|c|}{ Liraglutide $1.2 \mathrm{mg}$ vs. dapagliflozin $10 \mathrm{mg}$} & \multicolumn{3}{|c|}{ Liraglutide $1.8 \mathrm{mg}$ vs. dapagliflozin $10 \mathrm{mg}$} \\
\hline & $\begin{array}{l}\text { Incremental } \\
\text { costs (GBP) }\end{array}$ & $\begin{array}{l}\text { Incremental } \\
\text { QALYs }\end{array}$ & $\begin{array}{l}\text { ICER (GBP per } \\
\text { QALY gained) }\end{array}$ & $\begin{array}{l}\text { Incremental } \\
\text { costs (GBP) }\end{array}$ & $\begin{array}{l}\text { Incremental } \\
\text { QALYs }\end{array}$ & $\begin{array}{l}\text { ICER (GBP per } \\
\text { QALY gained) }\end{array}$ \\
\hline Base case & -11 & 0.039 & Dominant & 888.00 & 0.067 & 13,227 \\
\hline $\begin{array}{l}\text { Probabilistic } \\
\text { sensitivity analysis }\end{array}$ & 83 & 0.04 & 2178 & 1024.00 & 0.06 & 18,154 \\
\hline \multicolumn{7}{|l|}{ Treatment switch } \\
\hline $\begin{array}{l}\text { Treatment switch } \\
\text { at } 7.5 \%\end{array}$ & 225 & 0.038 & 5926 & 864.00 & 0.050 & 17,359 \\
\hline $\begin{array}{l}\text { Treatment switch } \\
\text { at } 5 \text { years }\end{array}$ & 863 & 0.039 & 21,856 & 2752.00 & 0.056 & 49,140 \\
\hline $\begin{array}{l}\text { Time horizon: } \\
10 \text { years }\end{array}$ & 825 & 0.016 & 52,203 & 2008.00 & 0.019 & 104,063 \\
\hline $\begin{array}{l}\text { Time horizon: } \\
20 \text { years }\end{array}$ & 286 & 0.031 & 9195 & 1062.00 & 0.037 & 28,944 \\
\hline $\begin{array}{l}\text { Time horizon: } \\
30 \text { years }\end{array}$ & -66 & 0.033 & Dominant & 850.00 & 0.059 & 14,354 \\
\hline $\begin{array}{l}\text { Time horizon: } \\
40 \text { years }\end{array}$ & -68 & 0.045 & Dominant & 896.00 & 0.060 & 14,964 \\
\hline \multicolumn{7}{|l|}{ Treatment effects } \\
\hline $\begin{array}{l}\text { Abolish BMI } \\
\text { treatment } \\
\text { differences }\end{array}$ & -24 & 0.051 & Dominant & 913.00 & 0.062 & 14,611 \\
\hline $\begin{array}{l}\text { Abolish SBP } \\
\text { treatment } \\
\text { differences }\end{array}$ & -237 & 0.058 & Dominant & 458.00 & 0.075 & 6119 \\
\hline \multicolumn{7}{|l|}{ Discount rate } \\
\hline $\begin{array}{l}0 \% \text { discount rate, } \\
\text { costs and } \\
\text { outcomes }\end{array}$ & -840 & 0.071 & Dominant & 95.00 & 0.126 & 754 \\
\hline $\begin{array}{l}6 \% \text { discount rate, } \\
\text { costs and } \\
\text { outcomes }\end{array}$ & 77,042 & 7.881 & 9776 & 95.00 & 0.126 & 754 \\
\hline Costs & & & & & & \\
\hline $\begin{array}{l}\text { Costs of } \\
\text { complications } \\
-10 \%\end{array}$ & -243 & 0.039 & Dominant & 841.00 & 0.067 & 12,535 \\
\hline
\end{tabular}


Table 5 continued

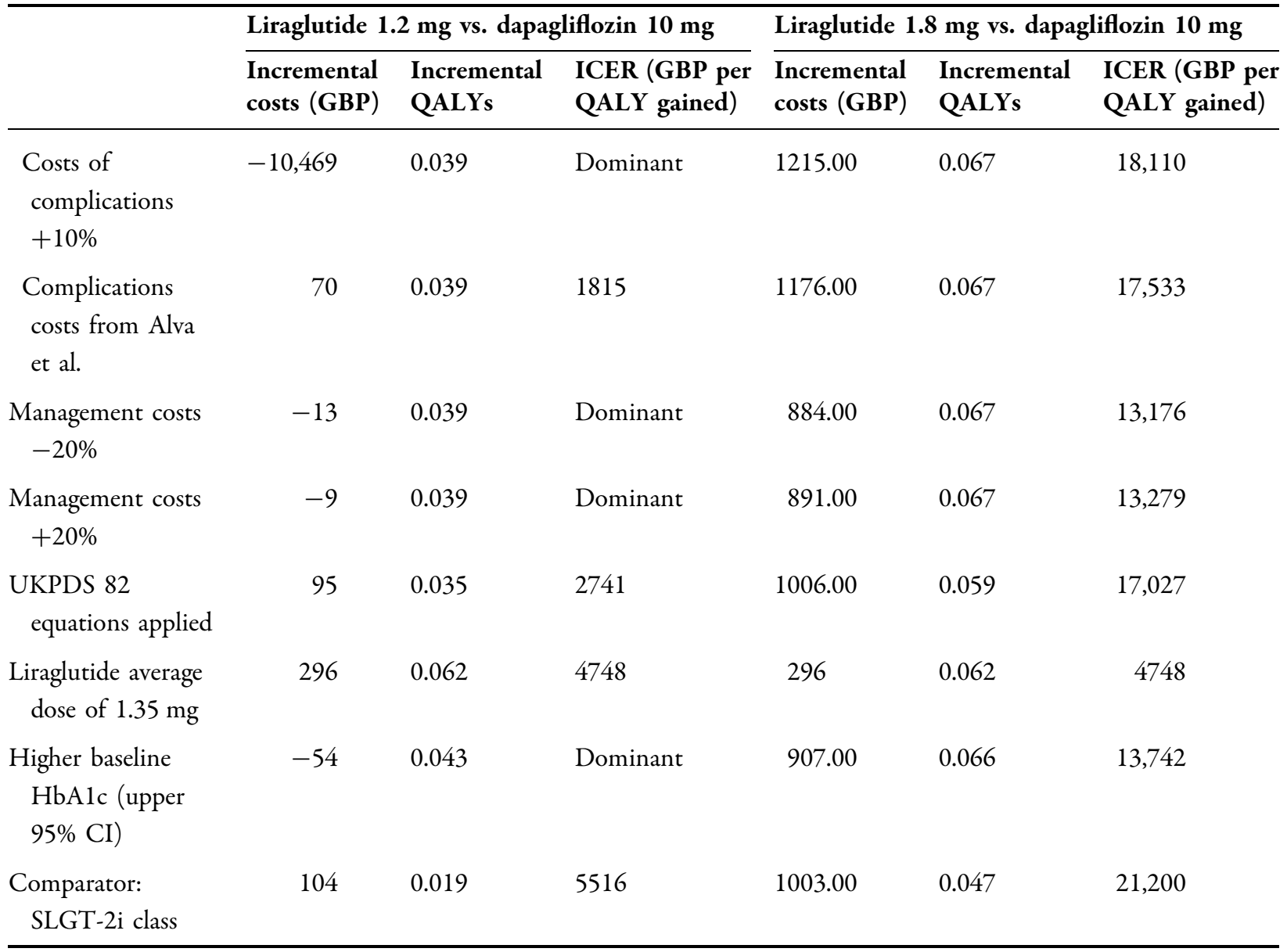

therapy. For T2DM patients on dual and on triple antidiabetic therapy, analysis results suggested modest cost savings and health benefits for liraglutide $1.2 \mathrm{mg}$ when compared to dapagliflozin $10 \mathrm{mg}$. Liraglutide $1.8 \mathrm{mg}$ was found to be cost-effective vs. dapagliflozin $10 \mathrm{mg}$ with an ICER below cost-effectiveness thresholds set by NICE (GBP 20,000-30,000) in both dual and triple therapy. Overall, observed differences between treatments in terms of costs and outcomes were modest, however, therefore both liraglutide doses and dapagliflozin $10 \mathrm{mg}$ may be considered comparable in terms of cost-effectiveness.

A range of scenario and sensitivity analyses were conducted to test the robustness of model results and generally found these to be robust to plausible variations in input parameters and modelling assumptions. Notable exceptions were sensitivity analyses of liraglutide $1.8 \mathrm{mg}$ reducing the time horizon to 10 years in the dual therapy analysis and extending the duration on treatment to 5 years in the triple therapy analysis.

The study has a number of limitations. Relative treatment effects of liraglutide and dapagliflozin have yet to be established in head-to-head RCTs; therefore, indirect estimates were derived from a network meta-analysis. As the NMA only included studies investigating dual therapy, relative estimates of effectiveness were assumed equivalent in patients on triple therapy. The CDM predicts long-term outcomes of T2DM patients based on the impact of therapies in short-term studies; although the CDM has been validated [8-10] as capable of reliably predicting long-term patient outcomes, direct evidence is lacking. The 
Table 6 Summary of sensitivity analyses: triple therapy

\begin{tabular}{|c|c|c|c|c|c|c|}
\hline & \multicolumn{3}{|c|}{ Liraglutide $1.2 \mathrm{mg}$ vs. dapagliflozin $10 \mathrm{mg}$} & \multicolumn{3}{|c|}{ Liraglutide $1.8 \mathrm{mg}$ vs. dapagliflozin $10 \mathrm{mg}$} \\
\hline & $\begin{array}{l}\text { Incremental } \\
\text { costs (GBP) }\end{array}$ & $\begin{array}{l}\text { Incremental } \\
\text { QALYs }\end{array}$ & $\begin{array}{l}\text { ICER (GBP } \\
\text { per QALY } \\
\text { gained) }\end{array}$ & $\begin{array}{l}\text { Incremental } \\
\text { costs (GBP) }\end{array}$ & $\begin{array}{l}\text { Incremental } \\
\text { QALYs }\end{array}$ & $\begin{array}{l}\text { ICER (GBP } \\
\text { per QALY } \\
\text { gained) }\end{array}$ \\
\hline Base case & -71.00 & 0.0640 & Dominant & 791.00 & 0.07 & 11,857 \\
\hline $\begin{array}{l}\text { Probabilistic } \\
\text { sensitivity analysis }\end{array}$ & 117.00 & 0.06 & 1850 & 893.00 & 0.06 & 16,156 \\
\hline \multicolumn{7}{|l|}{ Treatment switch } \\
\hline $\begin{array}{l}\text { Treatment switch } \\
\text { at } 7.5 \%\end{array}$ & -116.00 & 0.0490 & Dominant & 2713.00 & 0.05 & 52,269 \\
\hline $\begin{array}{l}\text { Treatment switch } \\
\text { at } 5 \text { years }\end{array}$ & 1080.00 & 0.0670 & 16,168 & 2061.00 & 0.02 & 130,413 \\
\hline $\begin{array}{l}\text { Time horizon: } \\
10 \text { years }\end{array}$ & 948.00 & 0.0230 & 40,698 & 1135.00 & 0.05 & 24,666 \\
\hline $\begin{array}{l}\text { Time horizon: } \\
20 \text { years }\end{array}$ & 220.00 & 0.0470 & 4705 & 924.00 & 0.05 & 18,219 \\
\hline $\begin{array}{l}\text { Time horizon: } \\
30 \text { years }\end{array}$ & 69.00 & 0.0720 & 957 & 850.00 & 0.05 & 15,712 \\
\hline $\begin{array}{l}\text { Time horizon: } \\
40 \text { years }\end{array}$ & 32.00 & 0.0640 & 503 & 2713.00 & 0.05 & 52,269 \\
\hline \multicolumn{7}{|l|}{ Treatment effects } \\
\hline $\begin{array}{l}\text { Abolish BMI } \\
\text { treatment } \\
\text { differences }\end{array}$ & -85.00 & 0.0710 & Dominant & 739.00 & 0.07 & 11,151 \\
\hline $\begin{array}{l}\text { Abolish SBP } \\
\text { treatment } \\
\text { differences }\end{array}$ & -388.00 & 0.0830 & Dominant & 170.00 & 0.08 & 2230 \\
\hline \multicolumn{7}{|l|}{ Discount rate } \\
\hline $\begin{array}{l}0 \% \text { discount rate, } \\
\text { costs and outcomes }\end{array}$ & -909.00 & 0.1120 & Dominant & -271.00 & 0.13 & Dominant \\
\hline $\begin{array}{l}6 \% \text { discount rate, } \\
\text { costs and outcomes }\end{array}$ & -909.00 & 0.1120 & Dominant & -271.00 & 0.13 & Dominant \\
\hline \multicolumn{7}{|l|}{ Costs } \\
\hline $\begin{array}{l}\text { Costs of } \\
\text { complications } \\
-10 \%\end{array}$ & -57.00 & 0.0640 & Dominant & 1094.00 & 0.07 & 16,404 \\
\hline
\end{tabular}


Table 6 continued

\begin{tabular}{|c|c|c|c|c|c|c|}
\hline & \multicolumn{3}{|c|}{ Liraglutide $1.2 \mathrm{mg}$ vs. dapagliflozin $10 \mathrm{mg}$} & \multicolumn{3}{|c|}{ Liraglutide $1.8 \mathrm{mg}$ vs. dapagliflozin $10 \mathrm{mg}$} \\
\hline & $\begin{array}{l}\text { Incremental } \\
\text { costs }(G B P)\end{array}$ & $\begin{array}{l}\text { Incremental } \\
\text { QALYs }\end{array}$ & $\begin{array}{l}\text { ICER (GBP } \\
\text { per QALY } \\
\text { gained) }\end{array}$ & $\begin{array}{l}\text { Incremental } \\
\text { costs (GBP) }\end{array}$ & $\begin{array}{l}\text { Incremental } \\
\text { QALYs }\end{array}$ & $\begin{array}{l}\text { ICER (GBP } \\
\text { per QALY } \\
\text { gained) }\end{array}$ \\
\hline $\begin{array}{l}\text { Costs of } \\
\text { complications } \\
+10 \%\end{array}$ & -416.00 & 0.0640 & Dominant & 993.00 & 0.06 & 16,770 \\
\hline $\begin{array}{l}\text { Complications costs } \\
\text { from Alva et al. }\end{array}$ & -169.00 & 0.0640 & Dominant & 978.00 & 0.07 & 14,663 \\
\hline $\begin{array}{l}\text { Management costs } \\
-20 \%\end{array}$ & -74.00 & 0.0640 & Dominant & 788.00 & 0.07 & 11,812 \\
\hline $\begin{array}{l}\text { Management costs } \\
+20 \%\end{array}$ & -69.00 & 0.0640 & Dominant & 794.00 & 0.07 & 11,903 \\
\hline $\begin{array}{l}\text { UKPDS } 82 \\
\text { equations applied }\end{array}$ & 212.00 & 0.0620 & 3404 & 1052.00 & 0.06 & 19,087 \\
\hline $\begin{array}{l}\text { Liraglutide average } \\
\text { dose of } 1.35 \mathrm{mg}\end{array}$ & 235.00 & 0.0660 & 3555 & 235.00 & 0.07 & 3555 \\
\hline $\begin{array}{l}\text { Higher baseline } \\
\text { HbA1c (upper } \\
95 \% \mathrm{CI} \text { ) }\end{array}$ & -112.00 & 0.0810 & Dominant & 425.00 & 0.08 & 5123 \\
\hline $\begin{array}{l}\text { Comparator: } \\
\text { SLGT-2i class }\end{array}$ & 120.00 & 0.0630 & 1913 & 983.00 & 0.07 & 14,956 \\
\hline
\end{tabular}

generalizability of the findings is limited by potential differences between RCT populations and patients who would receive these drugs in usual practice in the UK. Future research is warranted to generate evidence from real-world clinical data to help provide insights into the comparative real-life effectiveness of liraglutide and dapagliflozin and other SGLT-2is in terms of life expectancy or microvascular complications, including scenarios when these treatments are used in addition to insulin glargine.

Many different classes of products are available to treat T2DM. Often, new drugs are evaluated against very similar agents or against placebo. Liraglutide was previously compared with other GLP-1RA products in the UK $[4,5,28]$ and was recommended by the Scottish Medicines Consortium on the basis of acceptable cost-effectiveness compared to other
GLP-1RAs [29, 30]. Treatment decisions, however, need to weigh the merits and risks of different drug classes for a patient, but UK studies comparing liraglutide against drugs from other classes are infrequent. A 2011 study found that liraglutide at a dose of 1.2 and $1.8 \mathrm{mg}$ was associated with a cost per QALY gained of GBP 9851 and GBP 10,405, respectively, when compared to sitagliptin, and a cost per QALY gained of GBP 9449 and GBP 16,501, respectively, compared to glimepiride [31]. This study is the first of which we are aware that compares the cost-effectiveness of liraglutide to dapagliflozin from a UK perspective.

Whereas guidelines from the American Diabetes Association and the European Association for the Study of Diabetes suggest that GLP1-RA drugs are considered as options at first treatment escalation after failure on metformin [32], 

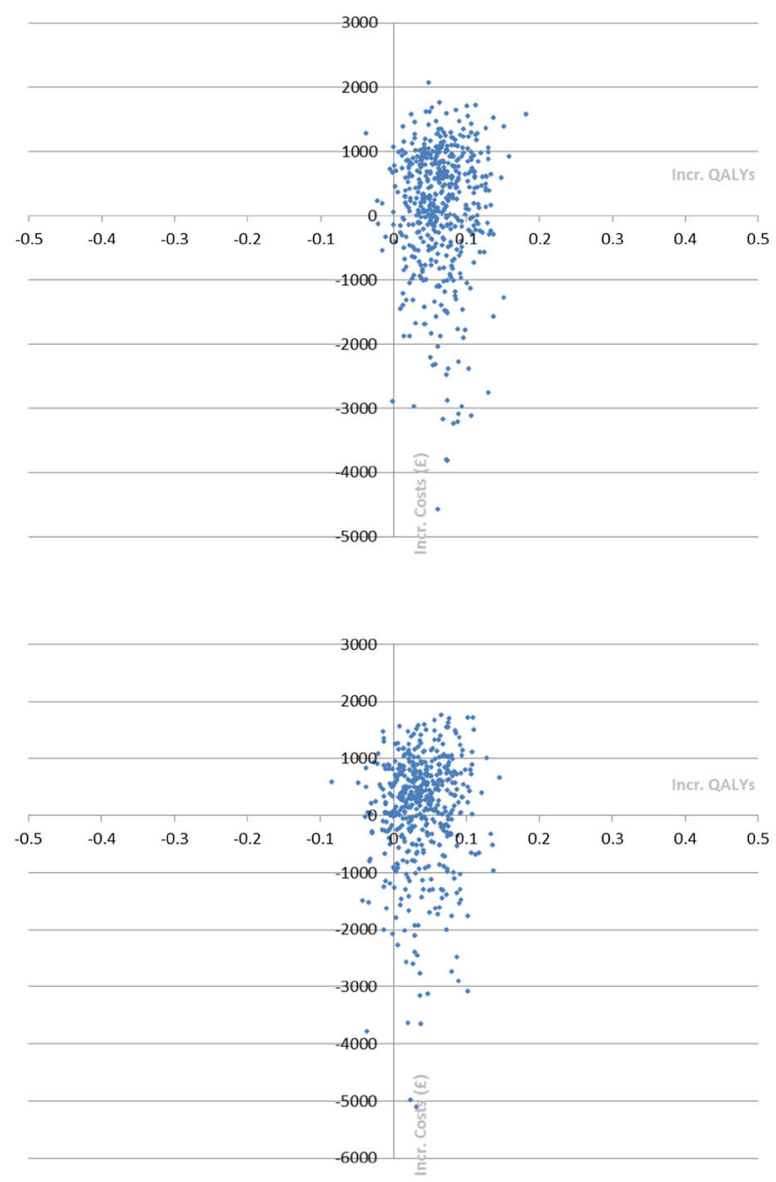

Fig. 1 Cost-effectiveness planes, liraglutide 1.2 and $1.8 \mathrm{mg}$ vs. dapagliflozin $10 \mathrm{mg}$. Upper left Liraglutide $1.2 \mathrm{mg}$ vs dapagliflozin $10 \mathrm{mg}$ in dual therapy; upper right liraglutide $1.8 \mathrm{mg}$ vs dapagliflozin $10 \mathrm{mg}$ in dual therapy; lower left

NICE guidelines recommend that GLP1-RA drugs are considered as an option after triple therapy with OADs (including SGLT-2is) has failed to achieve glycemic control. Potential reasons for placing GLP1-RA after OADs in the NICE pathway include the injected route of administration, gastrointestinal side effects, and higher cost. This study therefore evaluated the cost-effectiveness of treatment options which are recommended at different positions in the treatment pathway as per UK clinical guidelines.

In common with other studies, this economic evaluation relied on a simulation model to estimate the occurrence of long-term complications based on changes in diabetic risk factors shown in studies of 6-12 months
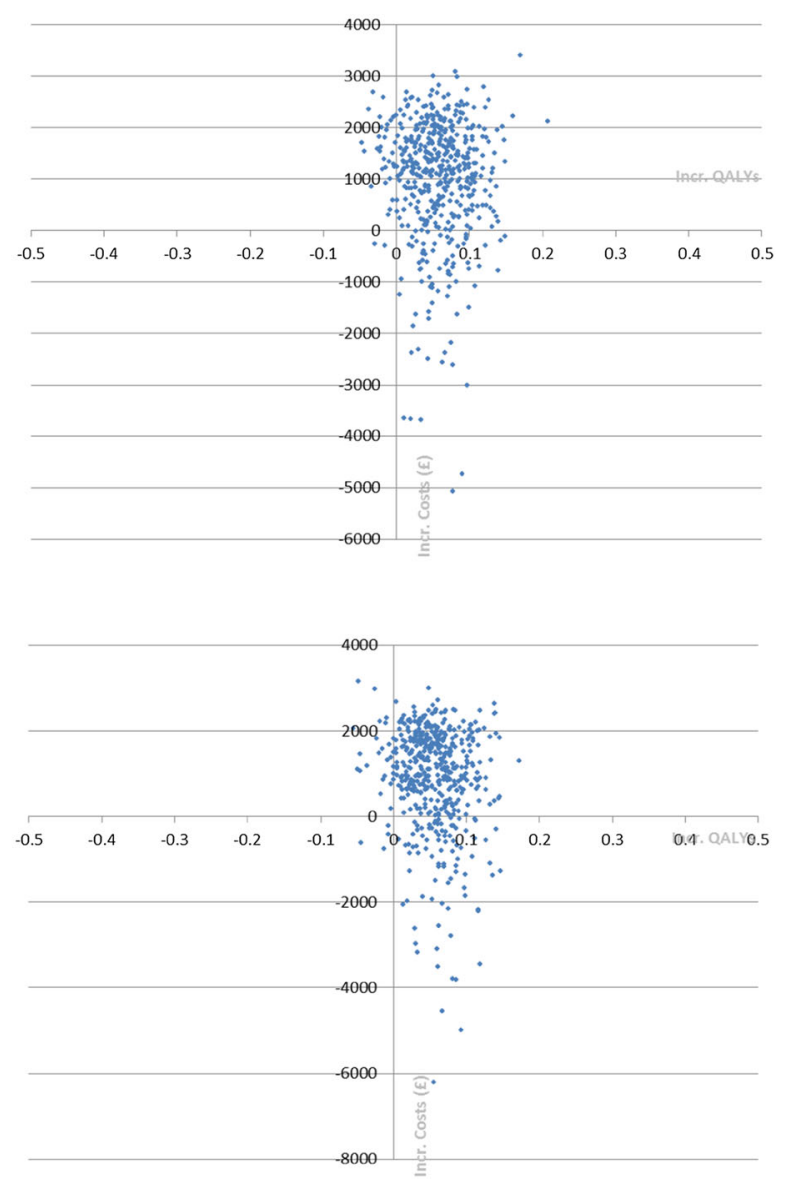

liraglutide $1.2 \mathrm{mg}$ vs dapagliflozin $10 \mathrm{mg}$ in triple therapy; lower right liraglutide $1.8 \mathrm{mg}$ vs dapagliflozin $10 \mathrm{mg}$ in triple therapy

duration. Long-term direct data on the impact of therapy on outcomes would be preferable to modelling. A recent study found that liraglutide reduces the incidence of cardiovascular events [33] in patients at high risk of cardiovascular disease, though results of similar studies with other agents have been mixed. Future evaluations might consider this direct evidence of impact on outcomes as well as making estimates based on risk factors.

\section{CONCLUSION}

This long-term health economic modelling analysis found that liraglutide $1.2 \mathrm{mg}$ was cost-effective when compared to dapagliflozin 

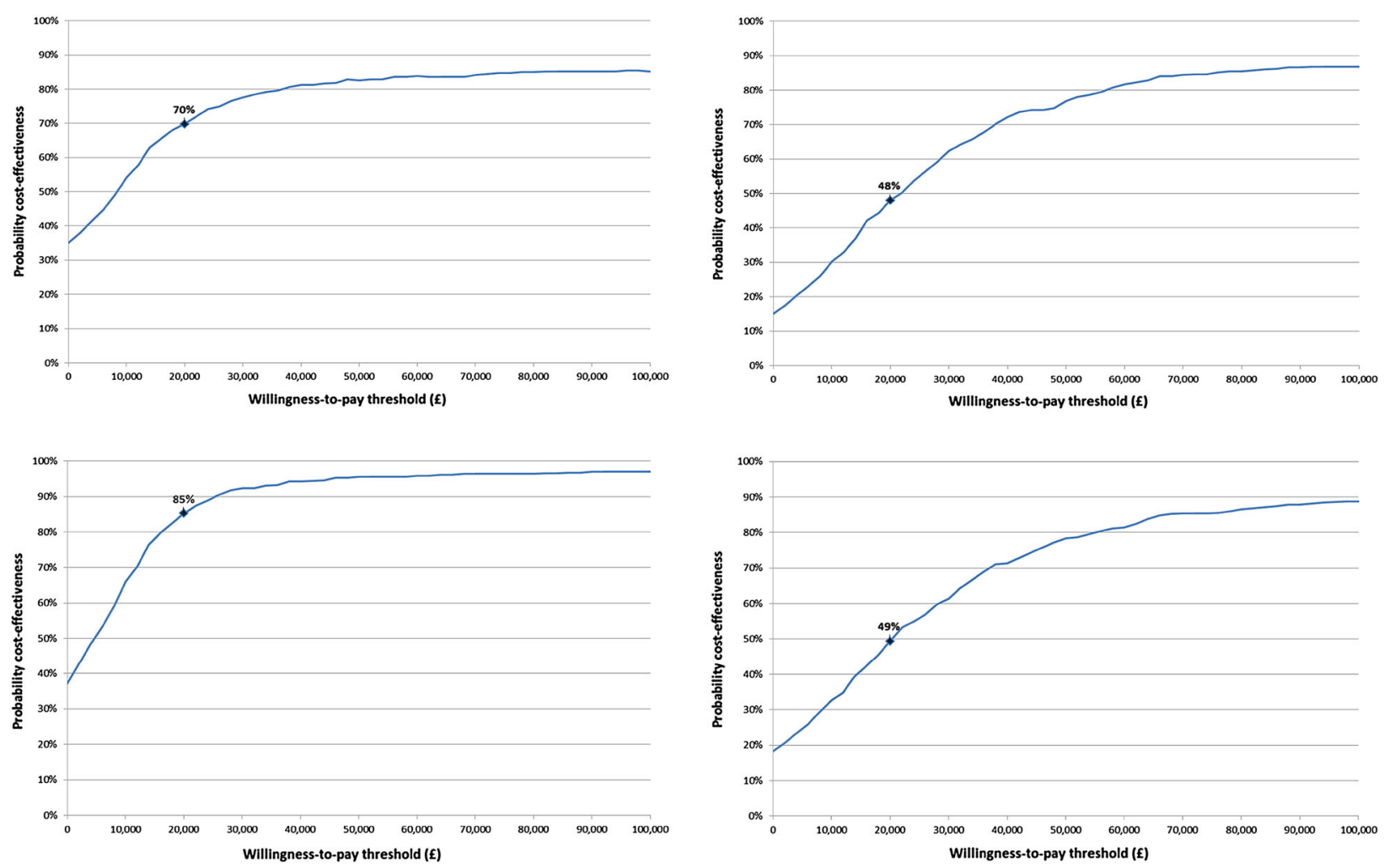

Fig. 2 Cost-effectiveness acceptability curves, liraglutide 1.2 and $1.8 \mathrm{mg}$ vs. dapagliflozin $10 \mathrm{mg}$. Upper left Liraglutide $1.2 \mathrm{mg}$ vs dapagliflozin $10 \mathrm{mg}$ in dual therapy; upper right liraglutide $1.8 \mathrm{mg}$ vs dapagliflozin $10 \mathrm{mg}$ in dual

therapy; lower left liraglutide $1.2 \mathrm{mg}$ vs dapagliflozin $10 \mathrm{mg}$ in triple therapy; lower right liraglutide $1.8 \mathrm{mg}$ vs dapagliflozin $10 \mathrm{mg}$ in triple therapy

$10 \mathrm{mg}$ in patients with T2DM as part of a dual and a triple antidiabetic therapy in the UK setting. Additionally, liraglutide $1.8 \mathrm{mg}$ is cost-effective vs. dapagliflozin $10 \mathrm{mg}$ under the cost-effectiveness thresholds set by NICE in both a dual and a triple combination therapy. Both dosages of liraglutide may therefore present a cost-effective treatment alternative in patients for whom an SGLT-2i therapy is considered.

\section{ACKNOWLEDGEMENTS}

Sponsorship for this study and article processing charges were funded by Novo Nordisk.

All named authors meet the International Committee of Medical Journal Editors (ICMJE) criteria for authorship for this manuscript, take responsibility for the integrity of the work as a

whole, and have given final approval to the version to be published.

Disclosures. Gabriela Vega-Hernandez is a full-time employee of Novo Nordisk Ltd. Radek Wojcik is a full-time employee of QuintilesIMS and served as paid consultant to Novo Nordisk for this study. Max Schlueter is a full-time employee of QuintilesIMS and served as paid consultant to Novo Nordisk for this study.

Compliance with Ethics Guidelines. This article does not contain any new studies with human or animal subjects performed by any of the authors.

Open Access. This article is distributed under the terms of the Creative Commons Attribution-NonCommercial 4.0 International License (http://creativecommons.org/licenses/ 
by-nc/4.0/), which permits any noncommercial use, distribution, and reproduction in any medium, provided you give appropriate credit to the original author(s) and the source, provide a link to the Creative Commons license, and indicate if changes were made.

\section{REFERENCES}

1. International Diabetes Federation. IDF diabetes atlas 2015. http://www.diabetesatlas.org. Accessed 18 Aug 2016.

2. Hex N, Bartlett C, Wright D, Taylor M, Varley D. Estimating the current and future costs of type 1 and type 2 diabetes in the UK, including direct health costs and indirect societal and productivity costs. Diabet Med. 2012;29(7):855-62.

3. National Institute of Health and Care Excellence (NICE). Clinical Guideline Update (NG28). Type 2 diabetes in adults: management. https://www.nice. org.uk/guidance/ng28. Accessed 18 Aug 2015.

4. Scott LJ. Liraglutide: a review of its use in adult patients with type 2 diabetes mellitus. Drugs. 2014;74(18):2161-74.

5. Ashley D, Vega G, Hunt B, Valentine WJ. Evaluating the cost-effectiveness of GLP-1 receptor agonists for the treatment of type 2 diabetes in the UK. Value Health. 2015;18(7):A606.

6. Fonseca T, Clegg J, Caputo G, Norrbacka K, Dilla T, Alvarez $\mathrm{M}$. The cost-effectiveness of exenatide once weekly compared with exenatide twice daily and insulin glargine for the treatment of patients with type two diabetes and body mass index $\geq 30 \mathrm{~kg} / \mathrm{m} 2$ in Spain. J Med Econ. 2013;16(7):926-38.

7. Huetson P, Palmer JL, Levorsen Ae, Fournier M, Germe M, McLeod E. Cost-effectiveness of once daily GLP-1 receptor agonist lixisenatide compared to bolus insulin both in combination with basal insulin for the treatment of patients with type 2 diabetes in Norway. J Med Econ. 2015;18(8):573-85.

8. McEwan P, Foos V, Palmer JL, Lamotte M, Lloyd A, Grant D. Validation of the IMS CORE Diabetes Model. Value Health. 2014;17(6):714-24.

9. Palmer AJ, Roze S, Valentine WJ, et al. The CORE Diabetes Model: projecting long-term clinical outcomes, costs and costeffectiveness of interventions in diabetes mellitus (types 1 and 2) to support clinical and reimbursement decision-making. Curr Med Res Opin. 2004;20(Suppl. 1):S5-26.
10. Palmer AJ, Roze S, Valentine WJ, et al. Validation of the CORE Diabetes Model against epidemiological and clinical studies. Curr Med Res Opin. 2004;20(sup1):S27-40.

11. Tzanetakos C, Melidonis A, Verras C, Kourlaba G, Maniadakis N. Cost-effectiveness analysis of liraglutide versus sitagliptin or exenatide in patients with inadequately controlled type 2 diabetes on oral antidiabetic drugs in Greece. BMC Health Serv Res. 2014;14(1):1.

12. Pratley RE, Nauck M, Bailey $T$, et al. Liraglutide versus sitagliptin for patients with type 2 diabetes who did not have adequate glycaemic control with metformin: a 26-week, randomised, parallel-group, open-label trial. Lancet. 2010;375(9724):1447-56.

13. Zinman B, Gerich J, Buse JB, et al. Efficacy and safety of the human glucagon-like peptide-1 analog liraglutide in combination with metformin and thiazolidinedione in patients with type 2 diabetes (LEAD-4 Met + TZD). Diabetes Care. 2009;32(7):1224-30.

14. World Health Organisation. WHO Global Alcohol Report 2014: Country Profiles. http://www.who.int/ entity/substance_abuse/publications/global_alcohol _report/msb_gsr_2014_2.pdf?ua=1. Accessed 1 Dec 2016.

15. Health \& Social Care Information Centre (HSCIC). Statistics on smoking: England 2014. http:// content.digital.nhs.uk/catalogue/PUB14988/smokeng-2014-rep.pdf. Accessed 1 Dec 2016.

16. Lorenzi M, Ploug UJ, Langer J, Skovgaard R, Jansen J. Liraglutide versus SGLT2 inhibitors in people with type 2 diabetes: a network meta-analysis. Poster 0226-P presented at the World Diabetes Conference, 30 November-4 December 2015, Vancouver, Canada.

17. World Health Organisation. WHOCC - ATC/DDD Index. World Health Organisation. Available from: http://www.whocc.no/atc_ddd_index/?showdescrip tion=yes\&code=A10AE04. Accessed 16 Dec 2015.

18. Clarke PM, Gray AM, Briggs A, et al. A model to estimate the lifetime health outcomes of patients with type 2 diabetes: the United Kingdom Prospective Diabetes Study (UKPDS) Outcomes Model (UKPDS no. 68). Diabetologia. 2004;47(10):1747-59.

19. Joint Formulary Committee. British national formulary 71. London: BMJ Group and Pharmaceutical Press; 2016.

20. MIMS Monthly Index of Medical Specialities (MIMS). http://www.mims.co.uk/. Accessed Jun 2016. 
21. Personal Social Services Research Unit. Unit costs of health and social care 2015. Personal Social Services Research Unit 2014. http://www.pssru.ac.uk/ project-pages/unit-costs/2015/. Accessed Jun 2016.

22. National Institute for Health and Care Excellence. Guide to the methods of technology appraisal 2013. National Institute for Health and Care Excellence 2015. https://www.nice.org.uk/article/pmg9/chapter/ foreword. Accessed 1 Dec 2016.

23. Beaudet A, Clegg J, Thuresson PO, Lloyd A, McEwan $P$. Review of utility values for economic modeling in type 2 diabetes. Value Health. 2014;17(4):462-70.

24. Bagust A, Beale S. Modelling EuroQol health-related utility values for diabetic complications from CODE-2 data. Health Econ. 2005;14(3):217-30.

25. Lauridsen JT, Lonborg J, Gundgaard J, Jensen HH. Diminishing marginal disutility of hypoglycaemic events: results from a time trade-off survey in five countries. Qual Life Res. 2014;23(9):2645-50.

26. Alva ML, Gray A, Mihaylova B, Leal J, Holman RR. The impact of diabetes-related complications on healthcare costs: new results from the UKPDS (UKPDS 84). Diabet Med. 2015;32(4):459-66.

27. Divino V, DeKoven M, Hallinan S, et al. Glucagon-like peptide-1 receptor agonist treatment patterns among type 2 diabetes patients in six European countries. Diabetes Ther. 2014;5(2):499-520.

28. Charokopou M, Chuang L, Verheggen B, Gibson D, Grandy S, Kartman B. Cost-effectiveness analysis of exenatide once-weekly versus dulaglutide, liraglutide and lixisenatide for the treatment of type 2 Diabetes Mellitus: an analysis from the UK NHS Perspective. Value Health. 2015;18(7):A606.

29. Scottish Medicines Consortium. Scottish Medicines Consortium liraglutide (Victoza). Scottish Medicines Consortium 2015 May 11. https://www. scottishmedicines.org.uk/SMC_Advice/Advice/1044 _15_liraglutide_Victoza/liraglutide_Victoza. Accessed 9 Nov 2016.

30. Scottish Medicines Consortium. Scottish Medicines Consortium liraglutide (Victoza). Scottish Medicines Consortium 2009 December 7. http://www.scottish medicines.org.uk/SMC_Advice/Advice/585_09_lirag lutide__Victoza_/liraglutide_Victoza_. Accessed 9 Nov 2016.

31. Davies MJ, Chubb BD, Smith IC, Valentine WJ. Cost-utility analysis of liraglutide compared with sulphonylurea or sitagliptin, all as add-on to metformin monotherapy in type 2 diabetes mellitus. Diabet Med. 2012;29(3):313-20.
32. Inzucchi SE, Bergenstal RM, Buse JB, et al. Management of hyperglycemia in type 2 diabetes, 2015: a patient-centered approach: update to a position statement of the American Diabetes Association and the European Association for the Study of Diabetes. Diabetes Care. 2015;38(1):140-9.

33. Marso SP, Daniels GH, Brown-Frandsen K, et al. Liraglutide and cardiovascular outcomes in type 2 diabetes. N Engl J Med. 2016;375(4):311-22.

34. Novo Nordisk. Clinical Trial Report. Liraglutide Effect and Action in Diabetes (LEAD 4): effect on glycemic control of liraglutide in combination with rosiglitazone plus metformin versus rosiglitazone plus metformin in type 2 diabetes (a twenty-six week double-blind parallel trial to investigate safety and efficacy). Trial Phase: 3a. 1-2-2008. Data on file.

35. Department of Health. NHS Reference Costs 2014 to 2015. https://www.gov.uk/government/publications/ nhs-reference-costs-2014-to-2015. Accessed 1 Dec 2016.

36. National Institute of Health and Care Excellence. NICE guideline CG48: MI-secondary prevention; Secondary prevention in primary and secondary care for patients following a myocardial infarcation. National Institute of Health and Care Excellence 2007. Available from: http://www.nice.org.uk/ guidance/cg48. Accessed 1 Dec 2016.

37. Cameron CG, Bennett HA. Cost-effectiveness of insulin analogues for diabetes mellitus. Can Med Assoc J. 2009;180(4):400-7.

38. Dyer MT, Goldsmith KA, Khan SN, et al. Clinical and cost-effectiveness analysis of an open label, single-centre, randomised trial of spinal cord stimulation (SCS) versus percutaneous myocardial laser revascularisation (PMR) in patients with refractory angina pectoris: the SPiRiT trial. Trials. 2008;9:40.

39. Youman P, Wilson K, Harraf F, Kalra L. The economic burden of stroke in the United Kingdom. Pharmacoeconomics. 2003;21(1):43-50.

40. National Institute of Health and Care Excellence. Chronic kidney disease: early identification and management of chronic kidney disease in adults in primary and secondary care (CG73). National Institute of Health and Care Excellence 2008. http://www.nice.org.uk/guidance/cg73. Accessed 1 Dec 2016.

41. National Institute for Health and Care Excellence. Type 2 diabetes: the management of type 2 diabetes (CG 87). National Institute for Health and Care Excellence 2014. http://www.nice.org.uk/guidance/ cg87. Accessed 1 Dec 2016. 
42. Chubb B, Jensen MM, Frier BM. Self-reported frequency and impact of non-severe hypoglycaemia in insulin-treated adults in the UK. Value Health. 2014;17(7):A354-5.

43. Clarke P, Gray A, Legood R, Briggs A, Holman R. The impact of diabetes-related complications on healthcare costs: results from the United Kingdom prospective diabetes study (UKPDS Study No. 65). Diabet Med. 2003;20(6):442-50.

44. Meads C, Hyde C. What is the cost of blindness? Br J Ophthalmol. 2003;87(10):1201-4.

45. Ghatnekar O, Willis M, Persson U. Cost-effectiveness of treating deep diabetic foot ulcers with Promogran in four European countries. J Wound Care. 2002;11(2):70-4.

46. Clarke P, Gray A, Holman R. Estimating utility values for health states of type 2 diabetic patients using the EQ-5D (UKPDS 62). Med Decis Mak. 2002;22(4):340-9.

47. Wasserfallen JB, Halabi G, Saudan P, et al. Quality of life on chronic dialysis: comparison between haemodialysis and peritoneal dialysis. Nephrol Dial Transpl. 2004;19(6):1594-9.

48. Kiberd BA, Jindal KK. Screening to prevent renal failure in insulin dependent diabetic patients: an economic evaluation. BMJ. 1995;311(7020):1595-9.

49. Fenwick EK, Xie J, Ratcliffe J, et al. The impact of diabetic retinopathy and diabetic macular edema on health-related quality of life in type 1 and type 2 diabetes. Investig Ophthalmol Vis Sci. 2012;53(2):677-84.

50. Lee AJ, Morgan CL, Morrissey M, Wittrup-Jensen K, Kennedy-Martin T, Currie CJ. Evaluation of the association between the EQ-5D index (health-related utility) and body mass index (obesity) in hospital-treated people with type 1 diabetes, type 2 diabetes and with no diagnosed diabetes. Diabet Med. 2005;22(11):1482-6.

51. Evans M, Khunti K, Mamdani M, et al. Health-related quality of life associated with daytime and nocturnal hypoglycaemic events: a time trade-off survey in five countries. Health Qual Life Outcomes. 2013;11(1):90.

52. Nauck M, Frid A, Hermansen K, et al. Efficacy and safety comparison of liraglutide, glimepiride, and placebo, all in combination with metformin, in type 2 diabetes: the LEAD (liraglutide effect and action in diabetes)-2 study. Diabetes Care. 2009;32(1):84-90.

53. Bailey CJ, Gross JL, Pieters A, Bastien A, List JF. Effect of dapagliflozin in patients with type 2 diabetes who have inadequate glycaemic control with metformin: a randomised, double-blind, placebo-controlled trial. Lancet. 2010;375(9733):2223-33.

54. Bolinder J, Ljunggren O, Kullberg J, et al. Effects of dapagliflozin on body weight, total fat mass, and regional adipose tissue distribution in patients with type 2 diabetes mellitus with inadequate glycemic control on metformin. J Clin Endocrinol Metab. 2012;97(3):1020-31.

55. Lambers Heerspink HJ, de ZD, Wie L, Leslie B, List J. Dapagliflozin a glucose-regulating drug with diuretic properties in subjects with type 2 diabetes. Diabetes Obes Metab. 2013;15(9):853-62. 